\title{
ADGRE1 Gene
}

National Cancer Institute

\section{Source}

National Cancer Institute. AD GRE1 Gene. NCI Thesaurus. Code C126950.

This gene is involved in immunity, cell adhesion and G protein-coupled receptor signaling. 